\title{
Synthesis of Nitroaromatic Compounds via Three-Component Ring Transformations
}

\author{
Song Thi Le ${ }^{1,2}$, Haruyasu Asahara 1,3,4 (D) and Nagatoshi Nishiwaki 1,3,*(D) \\ 1 School of Environmental Science and Engineering, Kochi University of Technology, Tosayamada, Kami, \\ Kochi 782-8502, Japan; lesong1986@gmail.com (S.T.L.); asahara@phs.osaka-u.ac.jp (H.A.) \\ 2 Center for Equipment and Labour Safety, Vietnam Institute for Building Materials (VIBM), Ministry of \\ Construction, 235 Nguyen Trai, Thanh Xuan, Hanoi 100000, Vietnam \\ 3 Research Center for Molecular Design, Kochi University of Technology, Tosayamada, Kami, \\ Kochi 782-8502, Japan \\ 4 Graduate School of Pharmaceutical Sciences, Osaka University, Yamadaoka 1-6, Suita, Osaka 565-0871, Japan \\ * Correspondence: nishiwaki.nagatoshi@kochi-tech.ac.jp; Tel.: +81-887-57-2517
}

check for updates

Citation: Le, S.T.; Asahara, H.; Nishiwaki, N. Synthesis of Nitroaromatic Compounds via Three-Component Ring Transformations. Molecules 2021, 26, 639. https://doi.org/10.3390/ molecules 26030639

Academic Editors: M. Graça P. M. S. Neves and Gianfranco Favi

Received: 11 January 2021

Accepted: 24 January 2021

Published: 26 January 2021

Publisher's Note: MDPI stays neutra with regard to jurisdictional claims in published maps and institutional affiliations.

Copyright: (c) 2021 by the authors. Licensee MDPI, Basel, Switzerland. This article is an open access article distributed under the terms and conditions of the Creative Commons Attribution (CC BY) license (https:// creativecommons.org/licenses/by/ $4.0 /)$.

\begin{abstract}
Methyl-3,5-dinitro-2-pyridone serves as an excellent substrate for nucleophilic-type ring transformation because of the electron deficiency and presence of a good leaving group. In this review, we focus on the three-component ring transformation (TCRT) of dinitropyridone involving a ketone and a nitrogen source. When dinitropyridone is allowed to react with a ketone in the presence of ammonia, TCRT proceeds to afford nitropyridines that are not easily produced by alternative procedures. Ammonium acetate can be used as a nitrogen source instead of ammonia to undergo the TCRT, leading to nitroanilines in addition to nitropyridines. In these reactions, dinitropyridone serves as a safe synthetic equivalent of unstable nitromalonaldehyde.
\end{abstract}

Keywords: dinitropyridone; three-component ring transformation; nitropyridine; nitroaniline; bicyclic intermediate; nitromalonaldehyde

\section{Introduction}

\subsection{Ring Transformation}

Ring transformation is a powerful synthetic method that accompanies the "scrap and build" of cyclic compounds. The general concept of this method is shown in Scheme 1. When a substrate $(\mathbf{A}+\mathbf{B})$ is reacted with a reagent $(\mathbf{C})$, the partial structure $(\mathbf{A})$ of the substrate is transferred to the reagent to construct a new ring system $(\mathbf{A}+\mathbf{C})$, simultaneously eliminating the leaving group (B). This reaction facilitates the synthesis of functionalized compounds that are not easily afforded by alternative procedures.

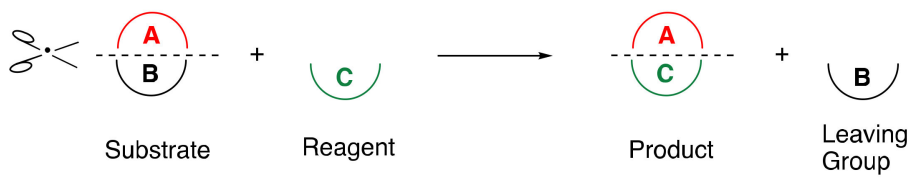

Scheme 1. General concept of the ring transformation.

There are four types of ring transformations, namely, Diels-Alder-type, decarboxylative, degenerate, and nucleophilic-type ring transformations (Scheme 2). The most commonly used methods are Diels-Alder-type ring transformation (type a) [1-3] and decarboxylative ring transformation (type b) [4-6], wherein the substrates have a good leaving group as a partial structure (molecular nitrogen and carbon dioxide, respectively). Degenerated ring transformation was energetically studied by van der Plas [7]. This reaction proceeds through the addition of nucleophile-ring opening-ring closure (ANRORC) mechanism. The nucleophilic-type ring transformation has not been studied extensively as compared to the other three ring transformations [8-13]. 
a) Diels-Alder type

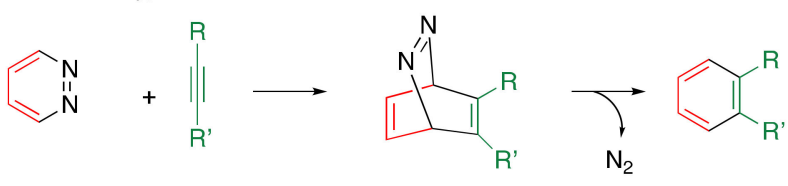

b) Decarboxylative type

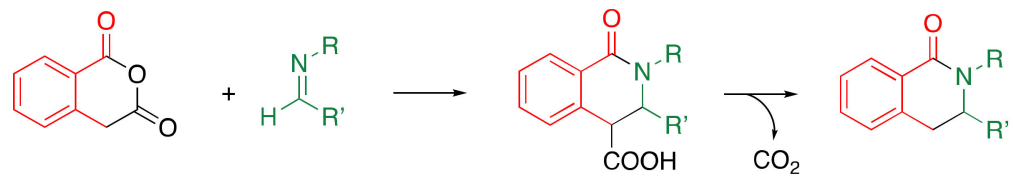

c) Degenerate type
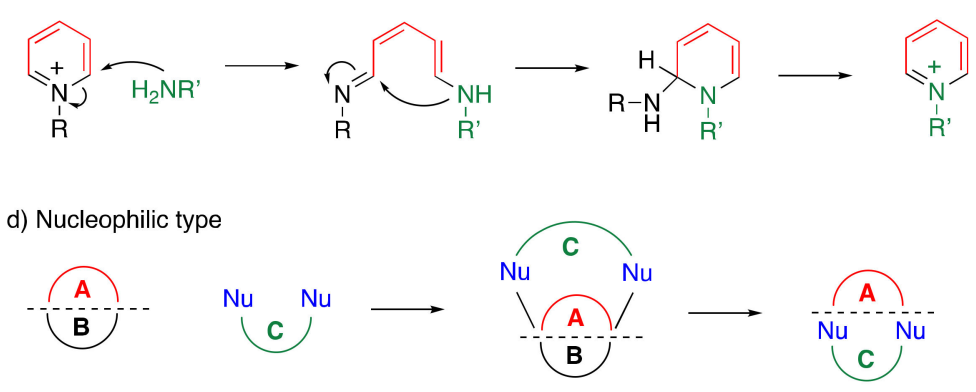

Scheme 2. General concepts of four kinds of ring transformations.

\subsection{Suitable Substrate for Nucleophilic-Type Ring Transformation}

To cause the nucleophilic-type ring transformation, a substrate requires three conditions: (1) high electron deficiency, (2) low aromatic stabilizing energy, and (3) the presence of a good leaving group as the partial structure. Based on these considerations, 1-methyl3,5-dinitro-2-pyridone (1) appears to be a suitable structure for this purpose (Figure 1). The electron-withdrawing nitro and carbonyl groups, besides the ring nitrogen atoms, diminish the electron density of this compound. As shown in the resonance form, though pyridone 1 exhibits aromaticity, it is easily destroyed because of the minimal contribution of the betaine resonance structure. In addition, the partial structure can be easily eliminated as a stable anion of nitroacetamide. When the ring transformation proceeds at the 4- and 6-positions accompanied by elimination of anionic nitroacetamide, the C4-C5-C6 moiety of pyridone $\mathbf{1}$ serves as the synthetic equivalent of nitromalonaldehyde (NMA-H). NMA-H is typically considered a synthon in retrosynthesis. However, NMA-H is too unstable to be isolated. Instead, its sodium salt (NMA-Na) has been widely used, although it should be handled carefully because of the explosive impurities [14]. Thus, it is necessary to develop a safe synthetic equivalent of NMA-H [15]. From this perspective, a nucleophilic-type ring transformation using pyridone $\mathbf{1}$ is a useful synthetic method for versatile nitro compounds because of its higher safety.

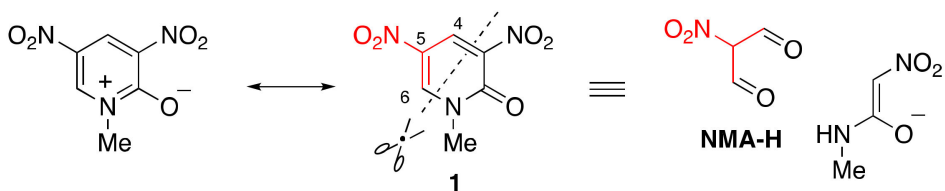

Figure 1. Resonance structure of dinitropyridone $\mathbf{1}$ and its partial structure.

Dinitropyridone 1 can be easily prepared from pyridine in three steps. After the conversion of pyridine to $N$-methylpyridinium salt 2 by dimethyl sulfate, oxidation with ferricyanide under alkaline conditions in one pot leads to the formation of 1-methyl-2pyridone 3 . The subsequent nitration of 3 by fuming nitric acid with sulfuric acid forms dinitropyridone 1 (Scheme 3). 


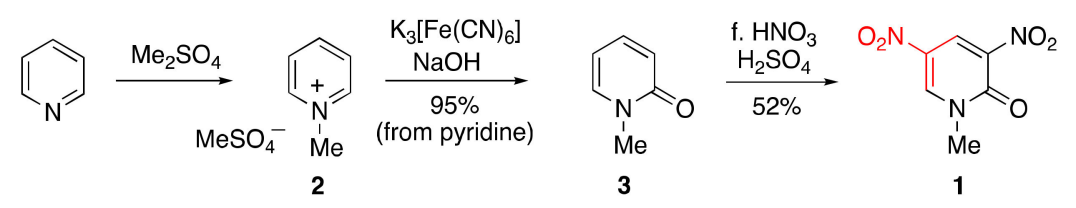

Scheme 3. Preparation of 1-methyl-3,5-dinitro-2-pyridone (1).

\section{Ring Transformation of 1 with Carbon Dinucleophiles}

\subsection{Aminolysis of Dinitropyridone $\mathbf{1}$}

Dinitropyridone 1 serves as a suitable substrate for nucleophilic-type ring transformation, which can be confirmed through aminolysis. The ring opening reaction of $\mathbf{1}$ proceeds upon treatment with amine, leading to nitro-substituted azadienamine 4 and dianionic product 5 (Scheme 4) [16]. The latter is formed by the addition of anionic nitroacetamide to pyridone 1 . This reaction is initiated by the addition of amines at the 4- and 6-positions. The subsequent cleavage of two $\mathrm{C}-\mathrm{C}$ bonds furnishes azadienamine 4, which indicates that anionic nitroacetamide serves as a good leaving group. However, it also serves as a nucleophile to form adduct 5 (Scheme 4 ).

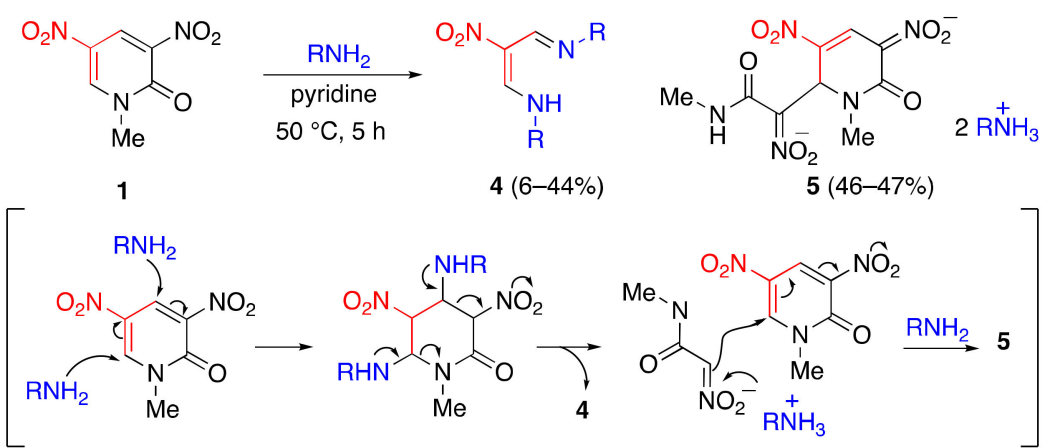

Scheme 4. Aminolysis of dinitropyridone $\mathbf{1}$ and a plausible mechanism for the aminolysis of $\mathbf{1}$.

Azadienamine 4 can be used as an excellent ligand to form diverse metal complexes [17-19]. From the perspective of ligand preparation, this reaction is not suitable, as dinitropyridone $\mathbf{1}$ is consumed by eliminated nitroacetamide. This problem is overcome by using 1-methyl-5-nitro-2-pyrimidinone (6) instead of dinitropyridone 1, as the eliminated urea is less nucleophilic than nitroacetamide and can thus avoid the consumption of 6 (Scheme 5) [20].

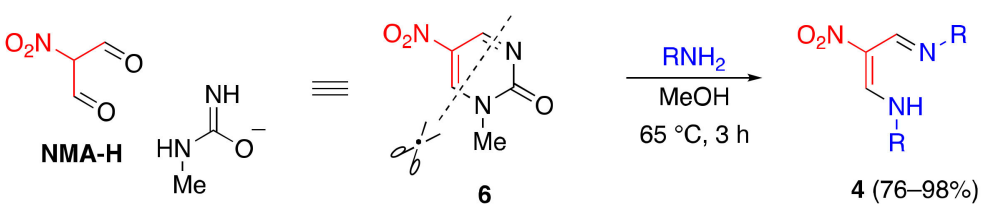

Scheme 5. Aminolysis of nitropyrimidinone 6.

\subsection{Reaction of Dinitropyridone 1 with 1,3-dicarbonyl Compounds}

The landmark work on nucleophilic-type ring transformation was achieved by Matsumura et al. (Table 1) [21,22]. When dinitropyridone $\mathbf{1}$ is allowed to react with sodium enolate of diethyl acetonedicarboxylate $\mathbf{7 a}$, the ring transformation can afford a high yield of 2,6-difunctionalized 4-nitrophenol 8a. This reaction can be applied to reagents $7 \mathbf{b}-\mathbf{d}$, each possessing one active methylene group, to afford the corresponding nitrophenols $8 b-d$. 
Table 1. Synthesis of functionalized 4-nitrophenols by ring transformation.

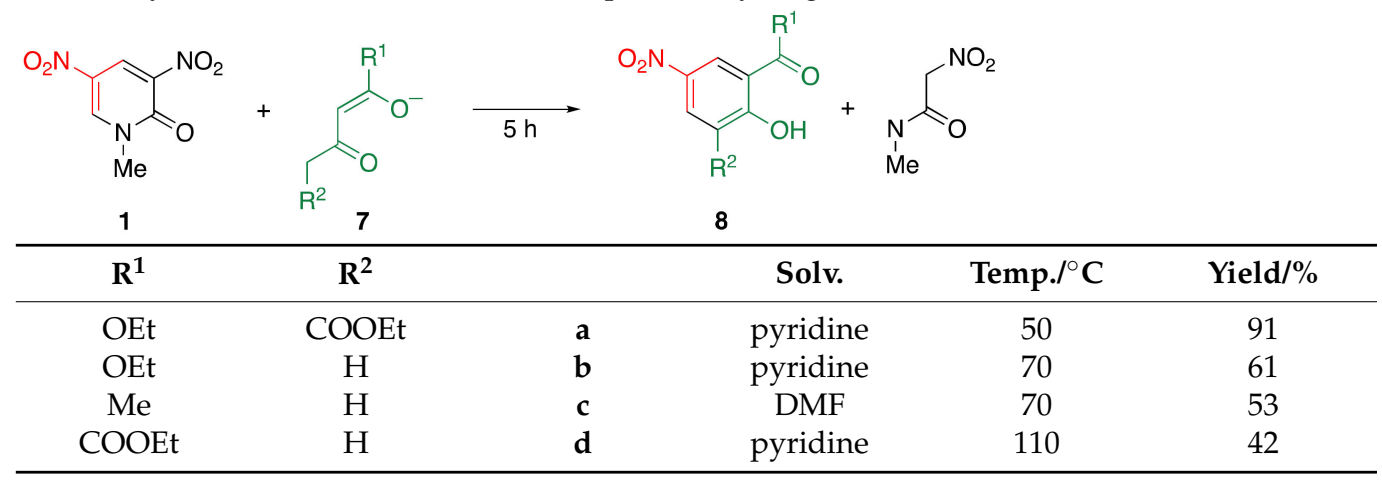

A plausible mechanism for this reaction is illustrated in Scheme 6. The enolate ion $\mathbf{7 b}$ attacks the 4-position of pyridone 1 to afford adduct intermediate $\mathbf{9}$, and the regenerated enolate 10 attacks the 6-position of 1, leading to bicyclic intermediate 11, from which the stable anionic nitroacetamide is eliminated to furnish nitrophenol $\mathbf{8 b}$; the bicyclic intermediate $\mathbf{1 1}$ can be isolated from the reaction mixture [21]. In addition, the reaction of nitropyrimidinone 6 and diethyl acetonedicarboxylate 7 a also affords bicyclic product 12 in high yield because unstable anionic urea cannot eliminate [23] (Scheme 7). Based on these results, the ring transformation is considered to proceed via bicyclic intermediates.<smiles>CCOC(=O)C=C(C)C(=O)[O-]</smiles>

1

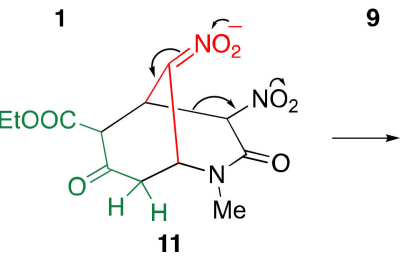

11<smiles>CCOC(=O)C1=CC([N+](=O)[O-])C=CC1=O</smiles><smiles>CCOC(=O)c1cc([N+](=O)[O-])ccc1O</smiles>

$8 b$

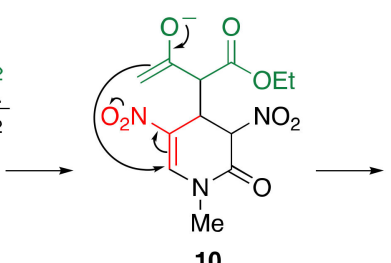

10<smiles>CCOC(=O)C1C=C([N+](=O)[O-])C(N(C)C(=O)C(C)(C)C(=O)N(C)CCC(C)C)C(=O)C1</smiles>

Scheme 6. A plausible mechanism for the formation of 8 .<smiles>O=c1ncc([N+](=O)[O-])cn1[Na]</smiles><smiles>CCOC(=O)CC(=O)CC(=O)OCC</smiles>

$7 a$

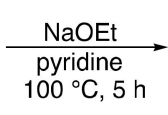

$100^{\circ} \mathrm{C}, 5 \mathrm{~h}$<smiles>CCOC(=O)C1=C(O)C([18O]CC)C2C(=O)NC1C2[N+](=O)[O-]</smiles>

Scheme 7. Synthesis of bicyclic compound 12.

\section{Three-Component Ring Transformation (TCRT)}

\subsection{General Concept of TCRT}

As mentioned previously, dinitropyridone $\mathbf{1}$ is highly reactive when used as the substrate in the nucleophilic-type ring transformation. The 1,3-dicarbonyl compounds 7 are excellent dinucleophilic reagents. However, the diversity of the available 1,3-dicarbonyl 
compounds 7 is low, which only affords few products 8 . If simple ketones can be used instead of 7, the synthetic utility of the ring transformation should be improved. In such cases, it is necessary to use a nitrogen source as ketone is a mononucleophilic reagent. This process is referred to as three-component ring transformation (TCRT) (Scheme 8).

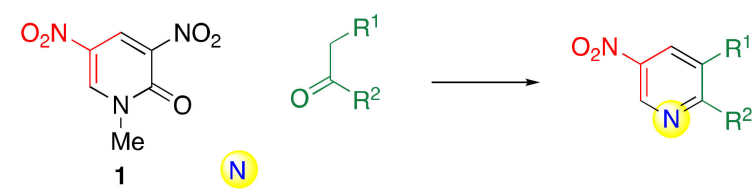

Scheme 8. The general concept of TCRT.

\subsection{TCRT Using Ammonia as the Nitrogen Source}

Tohda et al. studied the reaction of dinitropyridone $\mathbf{1}$ with ketones in the presence of ammonia (Table 2) [24]. When a methanol solution of pyridone $\mathbf{1}$ is heated with cyclohexanone 13a in the presence of ammonia (20 equiv.) at $70{ }^{\circ} \mathrm{C}$ (condition A), cyclohexa[ $b]$ pyridine 14a is obtained in $83 \%$ yield. However, this method suffers from the narrow scope of ketones. The TCRT using cyclopentanone $\mathbf{1 3 b}$ under the same conditions forms cyclopenta[ $b$ ]pyridine $\mathbf{1 4 b}$ in a considerably lower yield. When acetophenone 15a is allowed to react under the same conditions, TCRT proceeds similarly; however, the yield is low owing to the competitive ammonolysis of substrate 1. To overcome this disadvantage, it is important to employ severe conditions (heating with larger amounts of ammonia (140 equiv.) at $120^{\circ} \mathrm{C}$ in an autoclave (condition $\left.\mathrm{B}\right)$ ). This reaction is applicable to other aromatic ketones $\mathbf{1 5 b}-\mathbf{h}$ to afford the corresponding 2-(het)aryl-5-nitropyridines $\mathbf{1 6} \mathbf{b}-\mathbf{h}$, respectively. The ketone is not required to have an acetyl group, and propiophenone $\mathbf{1 5 i}$ undergoes the TCRT, leading to trisubstituted pyridine 16i. In the case of aromatic ketones $\mathbf{1 5 a} \mathbf{a} \mathbf{i}$, employment of condition B is effective for obtaining pyridines $\mathbf{1 6} \mathbf{a}-\mathbf{i}$ in better yields. In contrast, ketone $\mathbf{1 5} \mathbf{j}$ possessing an $\alpha^{\prime}$-proton forms pyridine $\mathbf{1 6} \mathbf{j}$ with better yield under condition A, as severe conditions cause side reactions. Indeed, pinacolone 15k without an $\alpha^{\prime}$-proton undergoes the TCRT more efficiently.

Table 2. TCRT using dinitropyridine 1, ketones, and ammonia, leading to nitropyridines.
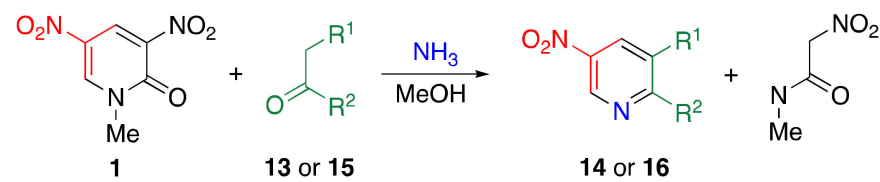

\begin{tabular}{|c|c|c|c|c|c|}
\hline \multicolumn{3}{|c|}{ Ketone } & \multirow{2}{*}{ Condition $^{1}$} & \multicolumn{2}{|c|}{ Product } \\
\hline $\mathbf{R}^{1}$ & $\mathbf{R}^{2}$ & & & & Yield/\% \\
\hline \multirow{2}{*}{\multicolumn{2}{|c|}{$\begin{array}{l}-\left(\mathrm{CH}_{2}\right)_{4}- \\
-\left(\mathrm{CH}_{2}\right)_{3}-\end{array}$}} & $13 a$ & A & $14 a$ & 83 \\
\hline & & $13 b$ & A & $14 b$ & 27 \\
\hline $\mathrm{H}$ & $\mathrm{Ph}$ & $15 a$ & A & $16 a$ & 44 \\
\hline $\mathrm{H}$ & $\mathrm{Ph}$ & $15 \mathbf{a}$ & B & $16 a$ & 81 \\
\hline $\mathrm{H}$ & $4-\mathrm{NH}_{2} \mathrm{C}_{6} \mathrm{H}_{4}$ & $15 b$ & B & $16 b$ & 44 \\
\hline $\mathrm{H}$ & $4-\mathrm{MeOC}_{6} \mathrm{H}_{4}$ & $15 c$ & B & $16 \mathrm{c}$ & 64 \\
\hline $\mathrm{H}$ & $4-\mathrm{MeC}_{6} \mathrm{H}_{4}$ & $15 d$ & $\mathrm{~B}$ & $16 d$ & 30 \\
\hline $\mathrm{H}$ & $4-\mathrm{NO}_{2} \mathrm{C}_{6} \mathrm{H}_{4}$ & $15 e$ & $\mathrm{~B}$ & $16 e$ & 27 \\
\hline $\mathrm{H}$ & 2-pyridyl & $15 f$ & B & $16 f$ & 72 \\
\hline $\mathrm{H}$ & 2-furyl & $15 \mathrm{~g}$ & B & $16 \mathrm{~g}$ & 62 \\
\hline $\mathrm{H}$ & 2-thienyl & $15 \mathrm{~h}$ & B & $16 \mathrm{~h}$ & 56 \\
\hline $\mathrm{Me}$ & $\mathrm{Ph}$ & $15 i$ & A & $16 \mathrm{i}$ & 10 \\
\hline $\mathrm{Me}$ & $\mathrm{Ph}$ & $15 \mathbf{i}$ & B & $16 \mathrm{i}$ & 37 \\
\hline $\mathrm{H}$ & $i-\operatorname{Pr}$ & 15j & $\mathrm{A}$ & 16j & 36 \\
\hline $\mathrm{H}$ & $i-\operatorname{Pr}$ & $15 j$ & B & $16 \mathbf{j}$ & 21 \\
\hline $\mathrm{H}$ & tert-Bu & $15 k$ & B & $16 k$ & 69 \\
\hline
\end{tabular}

${ }^{1}$ Condition A: ketone (2 equiv.), ammonia (20 equiv.), heating at $70{ }^{\circ} \mathrm{C}$ for $3 \mathrm{~h}$; Condition B: ketone (2 equiv.), ammonia (140 equiv.), heating at $120^{\circ} \mathrm{C}$ for $3 \mathrm{~h}$ in an autoclave. 
This TCRT efficiently proceeds under mild conditions (condition A) only when cyclohexanone 13a is used as the reagent. In other words, this protocol is an effective approach to $[b]$-fused 5-nitropyridines. This reaction is often employed for synthesizing biologically active compounds, medicines, and their synthetic intermediates.

Cyclohexa[b]pyridines 14c-f (Figure 2) are synthesized by TCRT using ammonia as a nitrogen source, in which functional groups such as carbamate, ester, and acetal are tolerated during the reaction [25-30]. Notably, multiple functionalities remain during the TCRT to afford a complex structure 14f. Piperidine-4-ones are usable as reagents in TCRT to produce 5,6,7,8-tetrahydro-1,6-naphthyridines 14g-m [31-37]. Not only $N$ alkylated derivatives $\mathbf{1 4} \mathbf{g}-\mathbf{i}$, but also $N$-aryl derivative $\mathbf{1 4} \mathbf{j}$ and $N$-acyl derivatives $\mathbf{1 4} \mathbf{k}-\mathbf{m}$ are available. When unsymmetrical pieridine-3-one is used, two condensed pyridines are formed, including 1,5-naphthyridine 14n [38]. Tetrahydropyran-4-one can be used for this method, which makes pyranopyridines 14o and 14p available [39-41].
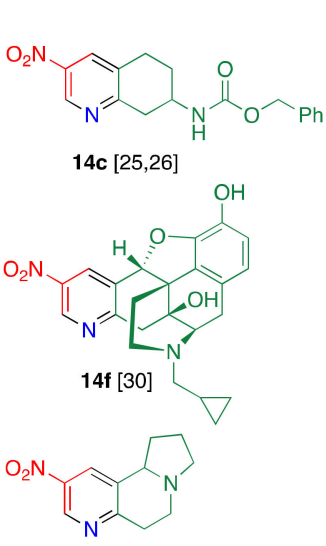

14i [33]<smiles>CC(C)(C)OC(=O)N1CCc2ncc([N+](=O)[O-])cc2C1</smiles>

$141[36]$<smiles>O=[N+]([O-])c1cnc2c(c1)COCC2</smiles>

$140[39,40]$

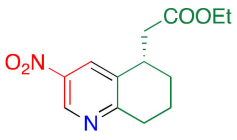

14d [27]<smiles>CN1CCc2ncc([N+](=O)[O-])cc2C1</smiles>

$14 \mathrm{~g}$ [31]<smiles>O=[N+]([O-])c1cnc2c(c1)CN(c1ccccc1Cl)CC2</smiles>

14j [34]<smiles>O=[N+]([O-])c1cnc2c(c1)CC1(CC2)OCCO1</smiles>

$14 \mathrm{e}[28,29]$<smiles>CCC1CN(Cc2ccccc2)Cc2cc([N+](=O)[O-])cnc21</smiles>

$14 \mathrm{~h}[32]$<smiles>O=C(c1ccccc1)N1CCc2ncc([N+](=O)[O-])cc2C1</smiles>

$14 k$ [35]

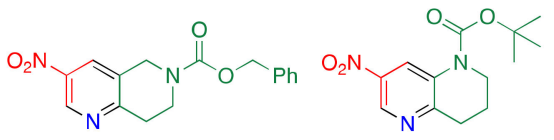

14m [37]

14n [38]

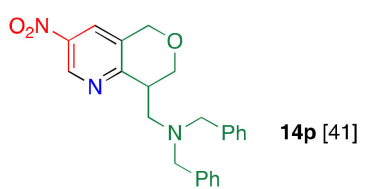

Figure 2. Nitropyridines condensed with a six-membered ring.

Cycloalkanones with different ring sizes can also be used as reagents in this TCRT (Figure 3). Cyclopenta[b]pyridine 14q, even though it has a complex structure, can be synthesized by altering the cyclopentanone to the corresponding one $[42,43]$. When pyrrolidine-3-one is used, 4-azaindole $14 \mathrm{r}$ is obtained [44]. 


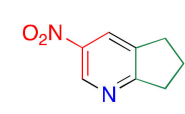

14b [42]<smiles>O=[N+]([O-])c1cnc2c(c1)CCCCC2</smiles>

14s $[45,46]$<smiles>CC1(C)COC2(CCCc3ncc([N+](=O)[O-])cc3CC2)OC1</smiles>

14v [48]

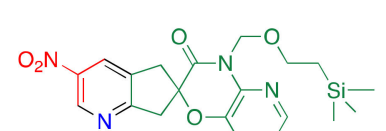

14q [43]<smiles>O=C(c1ccccc1)N1CCCc2ncc([N+](=O)[O-])cc2C1</smiles>

$14 \mathrm{t}[47]$

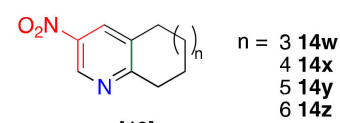

[49]

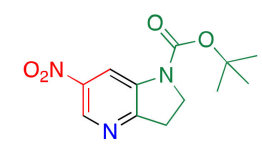

$14 r$ [44]

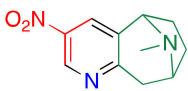

14u [36]

Figure 3. Nitropyridines condensed with a five-membered ring and with a larger ring.

Furthermore, cyclohepta[b]pyridine 14s can be synthesized upon treatment of pyridone 1 with cycloheptanone 13s [45,46]. When aza-containing cycloheptanone $\mathbf{1 3 t}$ and bridged cycloheptanone 13u are employed, cycloheptapyridine 14t [47] and tricyclic pyridines $\mathbf{1 4} \mathbf{u}$ [36] are formed. Nitropyridines condensed with a larger ring (from eight to eleven membered rings) can be prepared by only altering cycloalkanones [48,49].

\subsection{Reaction Mechanism of TCRT}

Two plausible mechanisms of TCRT are illustrated in Scheme 9. As mentioned in Section 2.1, both the 4- and 6-positions of dinitropyridone 1 are highly electrophilic, and are thus attacked by the enol form of $\mathbf{1 5 a}$ and ammonia to form adduct intermediate $\mathbf{1 7}$ (path a) [24]. The same product, 16a, is obtained when the ammonia and enol switch positions to attack. The amino group intramolecularly attacks the carbonyl group derived from 15a, leading to bicyclic intermediate 18, from which nitroacetamide is eliminated and accompanied by aromatization to afford nitropyridine 16a. Another possibility is that ketones are converted to enamines, which might serve as an actual nucleophile (path b) [50]. After adding the enamine to pyridone 1 , the amino group intramolecularly attacks the 6-position to form bicyclic intermediate 20, and elimination of nitroacetamide leads to the formation of nitropyridine $\mathbf{1 6 a}$.

a)

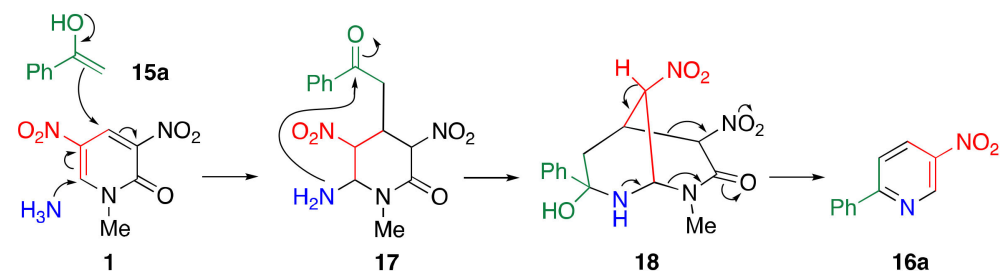

b)

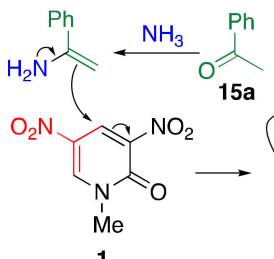

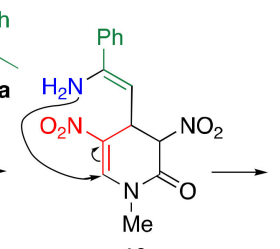

19

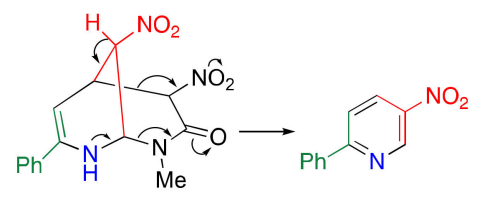

20

$16 a$

Scheme 9. Plausible mechanism of the TCRT. (a) Including attacks of two nucleophiles to pyridone 1. (b) Including an attack of enamine preformed in situ.

\subsection{TCRT Using Ammonium Acetate as the Nitrogen Source}

This TCRT proceeds efficiently when reactive cycloalkanones $\mathbf{1 3}$ are employed as reagents. In other words, when less reactive ketones such as $\mathbf{1 5 a}$ are used, both electrophilic sites of $\mathbf{1}$ are attacked by ammonia, which undergoes ammonolysis to consume pyridone 
1 competitively. Le et al. mitigated this problem by using a less nucleophilic ammonium acetate as a nitrogen source instead of ammonia.

When pyridone 1 is reacted with acetophenone 15a and three equivalents of ammonium acetate, nitropyridine 16a and a bicyclic product 21a are obtained (Table 3) [51]. The former is produced by TCRT, and the latter is formed by the insertion of 15a and nitrogen between the $\mathrm{N} 1$ and $\mathrm{C} 2$ positions of pyridone 1. Isolated 21a can be converted to 16a upon treatment with ammonium acetate, which indicates that there is equilibrium between these products. Thus, 16a is a thermodynamically controlled product, and 21a is a kinetically controlled product. The ratio of 16a increases as larger amounts of ammonium acetate or microwave heating are used. The use of larger amounts of ammonium acetate prolongs the actual reaction time, because it decomposes to gaseous ammonia and acetic acid upon heating.

Table 3. TCRT using pyridone 1 with different amounts of ammonium acetate.

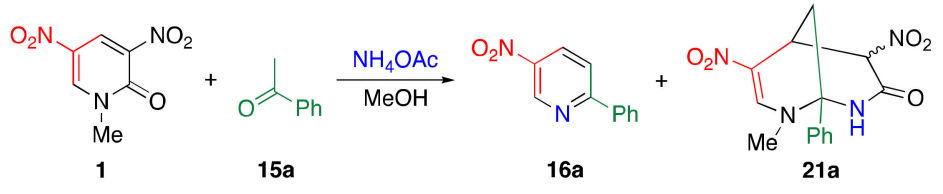

\begin{tabular}{|c|c|c|c|c|c|}
\hline \multirow{2}{*}{$\begin{array}{l}\mathrm{NH}_{4} \mathrm{OAc} \\
\text { lequiv. }\end{array}$} & \multirow{2}{*}{ Time/h } & \multicolumn{2}{|c|}{ Yield/\% } & \multirow{2}{*}{$\begin{array}{l}\text { Ratio of } \\
16 a / 21 a\end{array}$} & \multirow{2}{*}{$\begin{array}{c}\text { Ratio of } \\
\text { exo-21a/endo-21a }\end{array}$} \\
\hline & & $16 a$ & 21 & & \\
\hline 3 & 24 & 19 & 61 & $24 / 76$ & $56 / 44$ \\
\hline 5 & 24 & 43 & 46 & $48 / 52$ & $59 / 41$ \\
\hline 10 & 24 & 64 & 25 & $72 / 28$ & $70 / 30$ \\
\hline 15 & 24 & 79 & 0 & $100 / 0$ & - \\
\hline $5^{1}$ & 7 & 92 & 5 & $95 / 5$ & $60 / 40$ \\
\hline $15^{1}$ & 5 & 90 & 0 & $100 / 0$ & - \\
\hline
\end{tabular}

${ }^{1}$ Microwave heating is used.

The formation of bicyclic product 21a is considered to proceed as shown in Scheme 10. After addition of an enol form of $\mathbf{1 5 a}$ to the 4-position of $\mathbf{1}$, the acyl moiety of $\mathbf{2 2}$ is converted to enamine 19 by the ammonium ion. When the amino group of 19 intramolecularly attacks at the 6-position (path c), nitropyridine 16a is formed via bicyclic intermediate 20, as illustrated in Scheme 9. In contrast, the amino group of $\mathbf{1 9}$ attacks the carbonyl group, and degenerated ring transformation proceeds to afford 24. After prototropy leading to 25, the methylamino group attacks the imino functionality to afford bicyclic product 21a. However, the aminal structure of 21a is easily cleaved under acidic conditions to regenerate intermediate 19, which furnishes aromatized product 16a, predominantly under severe conditions.

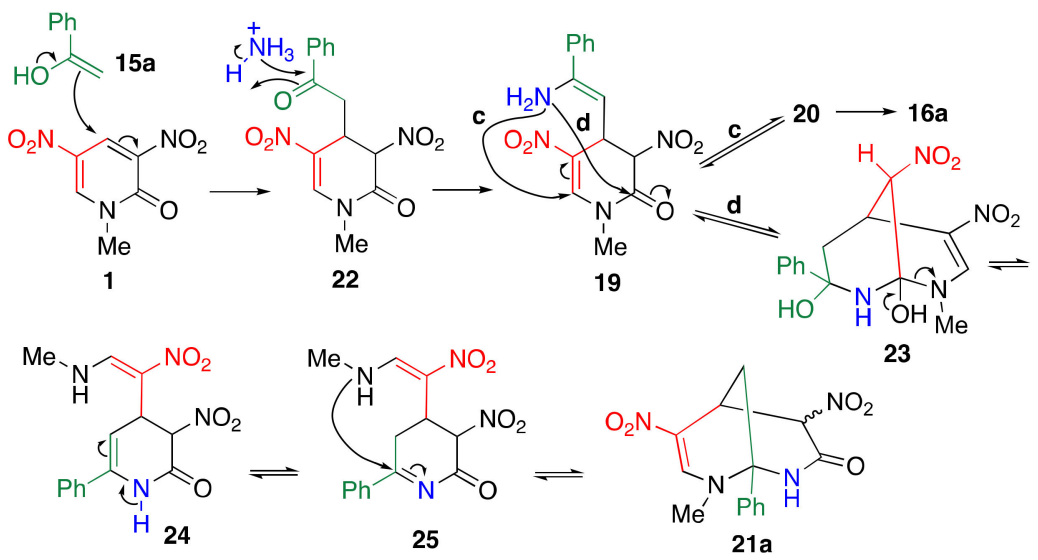

Scheme 10. A plausible mechanism for the formation of bicyclic product 21a. 
This method is applicable to other aromatic ketones $\mathbf{1 5 a}-\mathbf{q}$ (Table 4). TCRT efficiently proceeds in reactions using both electron-rich and electron-poor ketones, among which electron-poor ketones reveal lower reactivity and require larger amounts of ammonium acetate (longer reaction time). In cases of electron-poor ketones 15e, 15f, and 15o, bicyclic products 21e, 21f, and 210 are obtained, respectively. The ketone is not required to have an acetyl group, and ketones $\mathbf{1 5 i}$ and $\mathbf{1 5 q}$ afforded the corresponding trisubstituted pyridines $\mathbf{1 6} \mathbf{i}$ and $\mathbf{1 6 q}$ in almost quantitative yields, respectively.

Table 4. TCRT with other aromatic ketones 15.

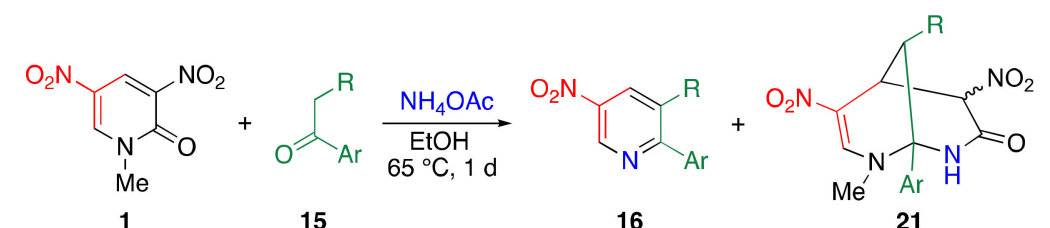

\begin{tabular}{|c|c|c|c|c|c|c|}
\hline \multicolumn{2}{|c|}{ Ketone } & & \multirow{2}{*}{$\begin{array}{c}\mathrm{NH}_{4} \mathrm{OAc} / \\
\text { equiv. }\end{array}$} & \multicolumn{3}{|c|}{ Yield/\% } \\
\hline Ar & $\mathbf{R}$ & & & 16 & 21 & $16+21$ \\
\hline $\mathrm{Ph}$ & $\mathrm{H}$ & $\mathbf{a}$ & 15 & 79 & 0 & 79 \\
\hline $4-\mathrm{MeOC}_{6} \mathrm{H}_{4}$ & $\mathrm{H}$ & $\mathrm{c}$ & $5^{1,2}$ & 95 & 0 & 95 \\
\hline $3-\mathrm{MeOC}_{6} \mathrm{H}_{4}$ & $\mathrm{H}$ & 1 & 10 & 97 & 0 & 97 \\
\hline $2-\mathrm{MeOC}_{6} \mathrm{H}_{4}$ & $\mathrm{H}$ & m & 5 & 94 & 0 & 94 \\
\hline $4-\mathrm{MeC}_{6} \mathrm{H}_{4}$ & $\mathrm{H}$ & d & 5 & 88 & 0 & 88 \\
\hline $4-\mathrm{ClC}_{6} \mathrm{H}_{4}$ & $\mathrm{H}$ & $\mathbf{n}$ & 10 & 96 & 0 & 96 \\
\hline $4-\mathrm{NO}_{2} \mathrm{C}_{6} \mathrm{H}_{4}$ & $\mathrm{H}$ & e & 15 & 93 & 2 & 95 \\
\hline 4-pyridyl & $\mathrm{H}$ & o & 15 & 66 & 33 & 99 \\
\hline 3-pyridyl & $\mathrm{H}$ & $\mathrm{p}$ & 15 & 97 & 0 & 97 \\
\hline 2-pyridyl & $\mathrm{H}$ & $\mathrm{f}$ & 15 & 80 & 12 & 92 \\
\hline 2-furyl & $\mathrm{H}$ & $\mathrm{g}$ & 5 & 87 & 0 & 87 \\
\hline 2-thienyl & $\mathrm{H}$ & h & 10 & 85 & 0 & 95 \\
\hline $\mathrm{Ph}$ & $\mathrm{Me}$ & i & $15^{1,3}$ & 98 & 0 & 98 \\
\hline $\mathrm{Ph}$ & $\operatorname{Pr}$ & $q$ & $15^{1,3}$ & 97 & 0 & 97 \\
\hline
\end{tabular}

${ }^{1}$ Microwave heating is used. ${ }^{2}$ For $6 \mathrm{~h} .{ }^{3}$ At $80{ }^{\circ} \mathrm{C}$ for $2 \mathrm{~h}$.

$\alpha, \beta$-Unsaturated ketones $\mathbf{2 6}$ and 28 can also be used for the TCRT (Tables 5 and 6) [52]. These ketones are less reactive, requiring 15-30 equivalents of ammonium acetate. Among the three styryl ketones, electron-rich ketone $\mathbf{2 6 b}$ reveals higher reactivity, which facilitates the approach to electron-deficient pyridone $\mathbf{1}$. The reaction with alkynyl ketones 28 efficiently furnishes alkynylpyridines 29 . When silylethynyl ketone $28 \mathrm{c}$ is used, the desilylated product $29 \mathrm{~d}$ is also obtained.

Table 5. TCRT with alkenyl ketones.

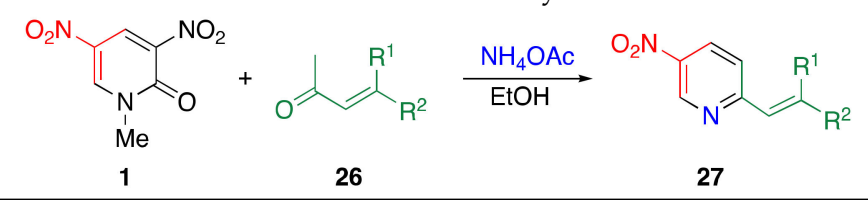

\begin{tabular}{|c|c|c|c|c|c|c|}
\hline \multicolumn{2}{|c|}{ Ketone } & & \multirow{2}{*}{$\begin{array}{c}\mathrm{NH}_{4} \mathrm{OAc} / \\
\text { equiv. }\end{array}$} & \multirow{2}{*}{ Temp. $/{ }^{\circ} \mathrm{C}$} & \multirow{2}{*}{ Time/h } & \multirow{2}{*}{ Yield/\% } \\
\hline $\mathbf{R}^{1}$ & $\mathbf{R}^{2}$ & & & & & \\
\hline $\mathrm{H}$ & $\mathrm{Ph}$ & $\mathbf{a}$ & 15 & $80^{1}$ & 4 & 82 \\
\hline $\mathrm{H}$ & $4-\mathrm{MeOC}_{6} \mathrm{H}_{4}$ & $\mathbf{b}$ & 30 & 65 & 24 & 94 \\
\hline $\mathrm{H}$ & $4-\mathrm{ClC}_{6} \mathrm{H}_{4}$ & c & 30 & $80^{1}$ & 4 & 75 \\
\hline $\mathrm{H}$ & $\mathrm{H}$ & $\mathrm{d}$ & 30 & 65 & 24 & 0 \\
\hline $\mathrm{Me}$ & $\mathrm{Me}$ & e & 15 & $80^{1}$ & 2 & 25 \\
\hline $\mathrm{H}$ & $\begin{array}{c}2,4,6- \\
\text { trimethylcyclohexyl }\end{array}$ & $\mathbf{f}$ & 30 & $80^{1}$ & 6 & 79 \\
\hline
\end{tabular}

\footnotetext{
${ }^{1}$ Microwave heating is used.
} 
Table 6. TCRT with alkynyl ketones 28 .<smiles>Cn1cc([N+](=O)[O-])cc([N+](=O)[O-])c1=O</smiles>

1

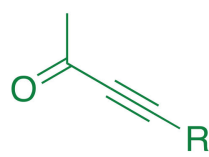

28

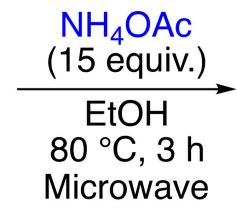

Microwave

\begin{tabular}{ccc}
\hline $\mathbf{R}$ & & Yield/\% \\
\hline $\mathrm{Ph}$ & $\mathbf{a}$ & 87 \\
$\mathrm{Et}$ & $\mathbf{b}$ & 80 \\
$\mathrm{Me}_{3} \mathrm{Si}$ & $\mathbf{c}$ & $\mathbf{2 9 c} 24 / \mathbf{2 9 d} 60^{1}$ \\
\hline
\end{tabular}

${ }^{1}$ Desilylated product $29 \mathrm{~d}(\mathrm{R}=\mathrm{H})$ is also obtained.

For the $\mathrm{C}-\mathrm{C}$ bond formation on the pyridine framework, the Heck, Suzuki, Stille, and Sonogashira reactions are commonly used. However, these methods require the use of poisonous and expensive transition metals and a purification step to avoid metal contamination of the products. In addition, troublesome multistep reactions are necessary to prepare the substrates for these reactions (2-halo-5-nitropyridines). Thus, the TCRT is a metal-free supplementary method for the abovementioned reactions.

\subsection{Preparation of 3-substituted 5-nitropyridines 31 by TCRT}

When dinitropyridone $\mathbf{1}$ is allowed to react with aldehyde $\mathbf{3 0}$ and ammonia as a nitrogen source, TCRT does not occur at all. In such a case, the use of ammonia/ammonium acetate as a mixed nitrogen source is effective to undergo the TCRT. However, the yields of $\mathbf{3 1}$ are low, as highly reactive aldehyde $\mathbf{3 0}$ causes side reactions such as self-condensation $[24,53]$. Using only ammonium acetate helps the TCRT to afford the corresponding pyridines 31a-f in moderate to high yields (Table 7) [54]. This protocol facilitates the introduction of not only a bulky alkyl group such as a tert-butyl but also an aromatic group into the pyridine framework with simple experimental manipulations.

Table 7. TCRT with aldehydes 30.

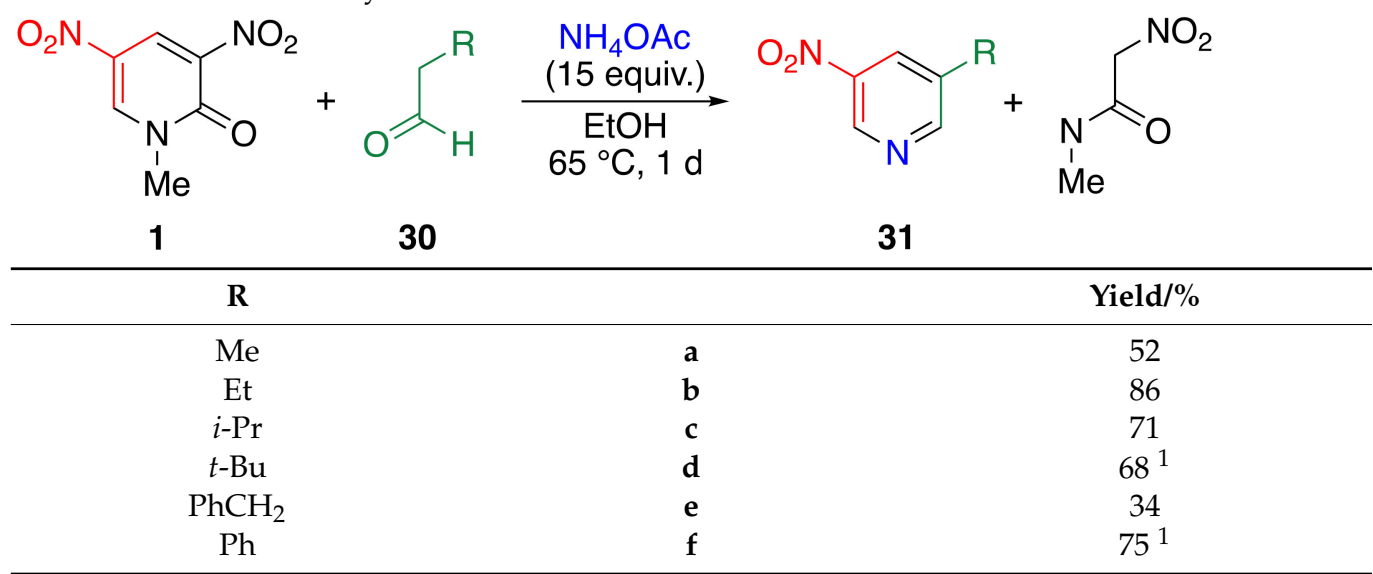

Microwave heating is used.

\subsection{TCRT Using Cyclic Ketones $\mathbf{1 3}$}

Dinitropyridone $\mathbf{1}$ undergoes TCRT with cycloalkanone $\mathbf{1 3}$ in the presence of ammonium acetate, leading to cycloalka[b]pyridines 14 (Table 8) [55]. Cycloalkanones 13 with various ring sizes efficiently react under conventional heating (Condition $\mathrm{C}$ ) to afford the corresponding nitropyridines condensed with five-, six-, seven-, and eight-membered rings. The reaction time is considerably shortened by using microwave heating (Condition D). In this reaction, the unsymmetrical ketone, 2-methylcyclohexanone 13aa, which reacts at the 6-position not at the 2-position, as aromatization is prevented by a methyl group in the 
latter case, can also be used as a reagent. When 2-cyclohexenone 13ab is used, migration of the double bond is observed, which may occur after the addition of ketone 13ab to pyridone 1 and the subsequent conversion to dienamine 32ab, leading to the formation of dienamine $33 \mathbf{a b}$ (Scheme 11).

Table 8. TCRT with cycloalkanones 13.<smiles>Cn1cc([N+](=O)[O-])cc([N+](=O)[O-])c1=O</smiles>

1

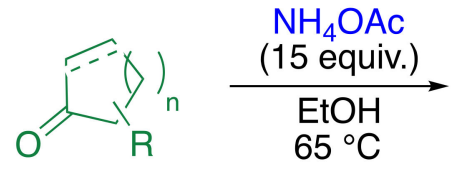

13

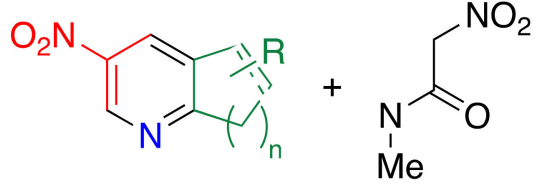

14

Condition C: conventional heating

Condition D: microwave heating

\begin{tabular}{|c|c|c|c|c|c|}
\hline \multirow{2}{*}{ Substrate } & \multirow[t]{2}{*}{ Product } & \multicolumn{2}{|c|}{ Condition C } & \multicolumn{2}{|c|}{ Condition D } \\
\hline & & Time/h & Yield/\% & Time/h & Yield/\% \\
\hline & $14 b$ & 24 & 67 & 2 & 87 \\
\hline & $14 a$ & 24 & 95 & 1 & 97 \\
\hline & $14 \mathrm{~s}$ & 24 & 94 & 1 & 91 \\
\hline & $14 w$ & 24 & 85 & 1 & 95 \\
\hline & 14aa & 24 & 83 & 2 & 86 \\
\hline & $14 a b$ & 24 & 59 & 3 & 89 \\
\hline
\end{tabular}

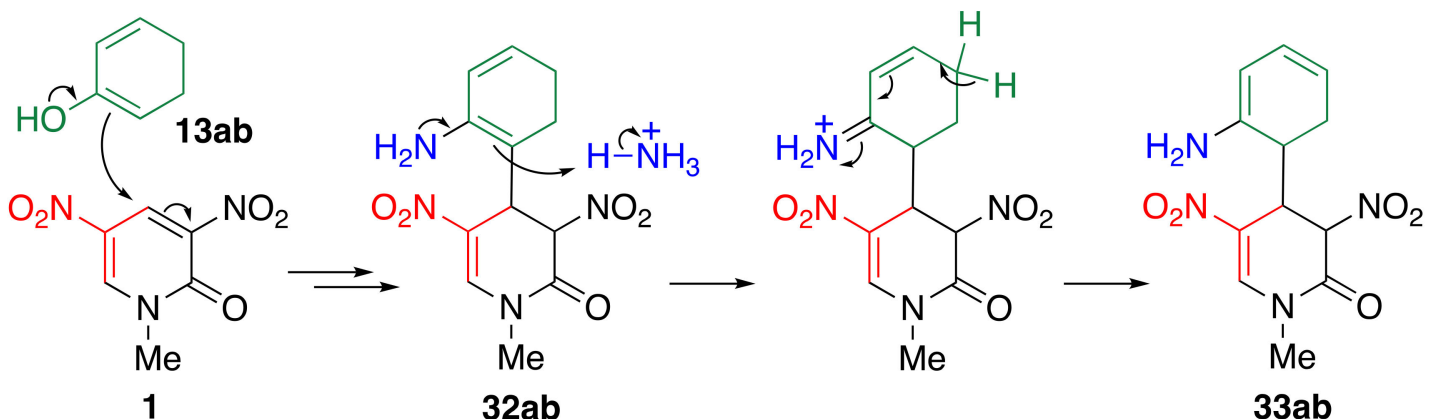

Scheme 11. A plausible mechanism for the double bond migration.

\subsection{Reconsideration about the Reaction Mechanism of TCRT}

As shown in Scheme 10, the TCRT is initiated by the addition of the enol form of a ketone to the 4-position of dinitropyridone 1, after which the acyl group of adduct 19 is converted to enamine $\mathbf{2 0}$ by the ammonium ion. Enamine has an ambident property, where $\beta$-carbon is generally more nucleophilic than the amino group. In the case of adduct intermediate 19 derived from aromatic ketone 15, $\mathrm{N}$-attack (path c) forms a sixmembered ring to afford bicyclic intermediate 20, from which nitropyridine $\mathbf{1 6}$ is obtained, accompanied by the elimination of nitroacetamide (Scheme 12). In contrast, if a C-attack (path e) occurs, sterically strained four-membered ring $\mathbf{3 4}$ is formed. Hence, nitropyridine $\mathbf{1 6}$ is formed as the sole product in this TCRT. In cases of $\alpha, \beta$-unsaturated ketones 26 and 
28 and aldehydes 30 , a similar reactivity is observed, as these carbonyl compounds have only one kind of $\alpha$-hydrogen.

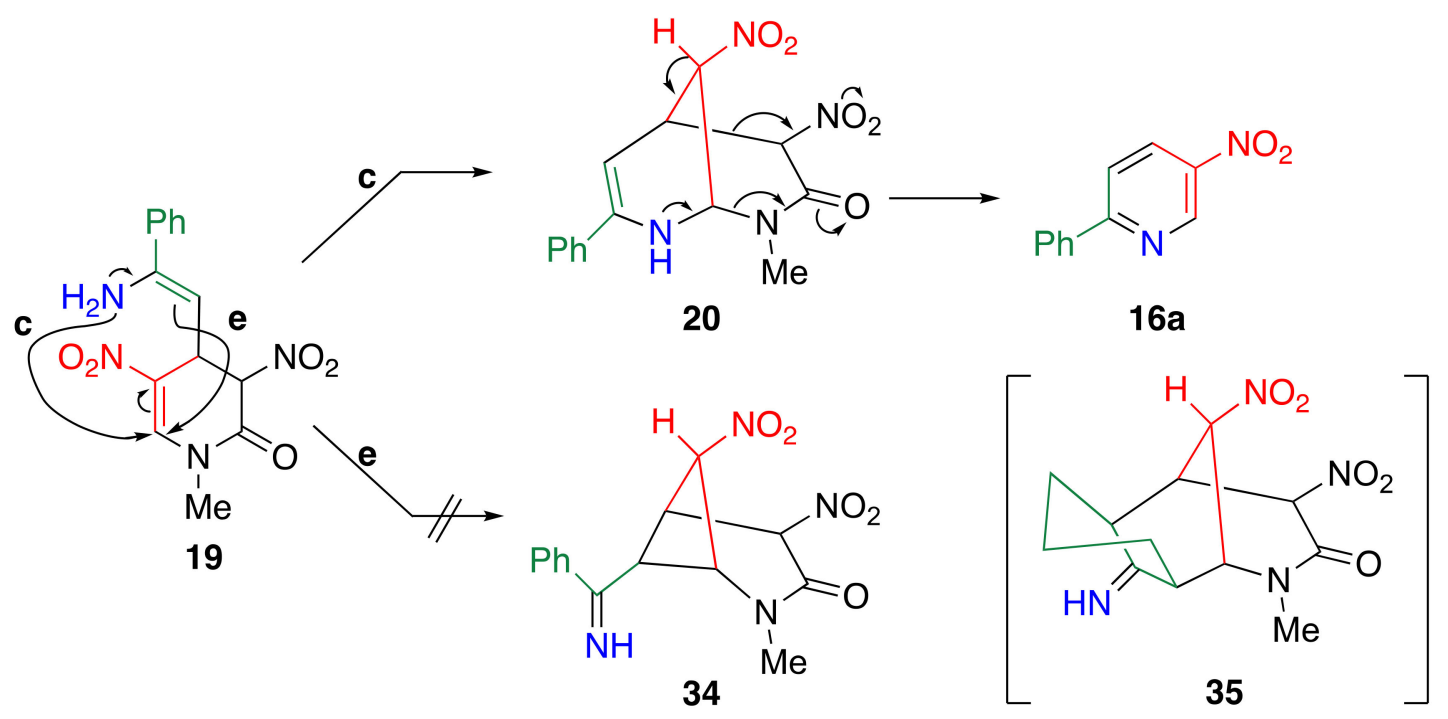

Scheme 12. Plausible mechanism using aromatic ketone 15 and cycloalkanone 13.

In the case of aliphatic ketones 36, two types of enamines (37 and 38) are possibly formed (Scheme 13). While the intermediate 37 cannot cause a $C$-attack similar to 19 , the intermediate 38 can cause both $N$ - and $C$-attacks to furnish bicyclic intermediates 41 and $\mathbf{4 2}$, respectively. From bicyclic intermediates $\mathbf{4 0}$ and $\mathbf{4 1}$, nitropyridine $\mathbf{4 3}$ is formed. In contrast, 2,6-disubstituted 4-nitroaniline $\mathbf{4 4}$ should form when nitroacetamide is eliminated from bicyclic intermediate $\mathbf{4 2}$. Thus, two ring-transformed products ( $\mathbf{4 3}$ and $\mathbf{4 4}$ ) are yielded when aliphatic ketones $\mathbf{3 6}$ are used as reagents.

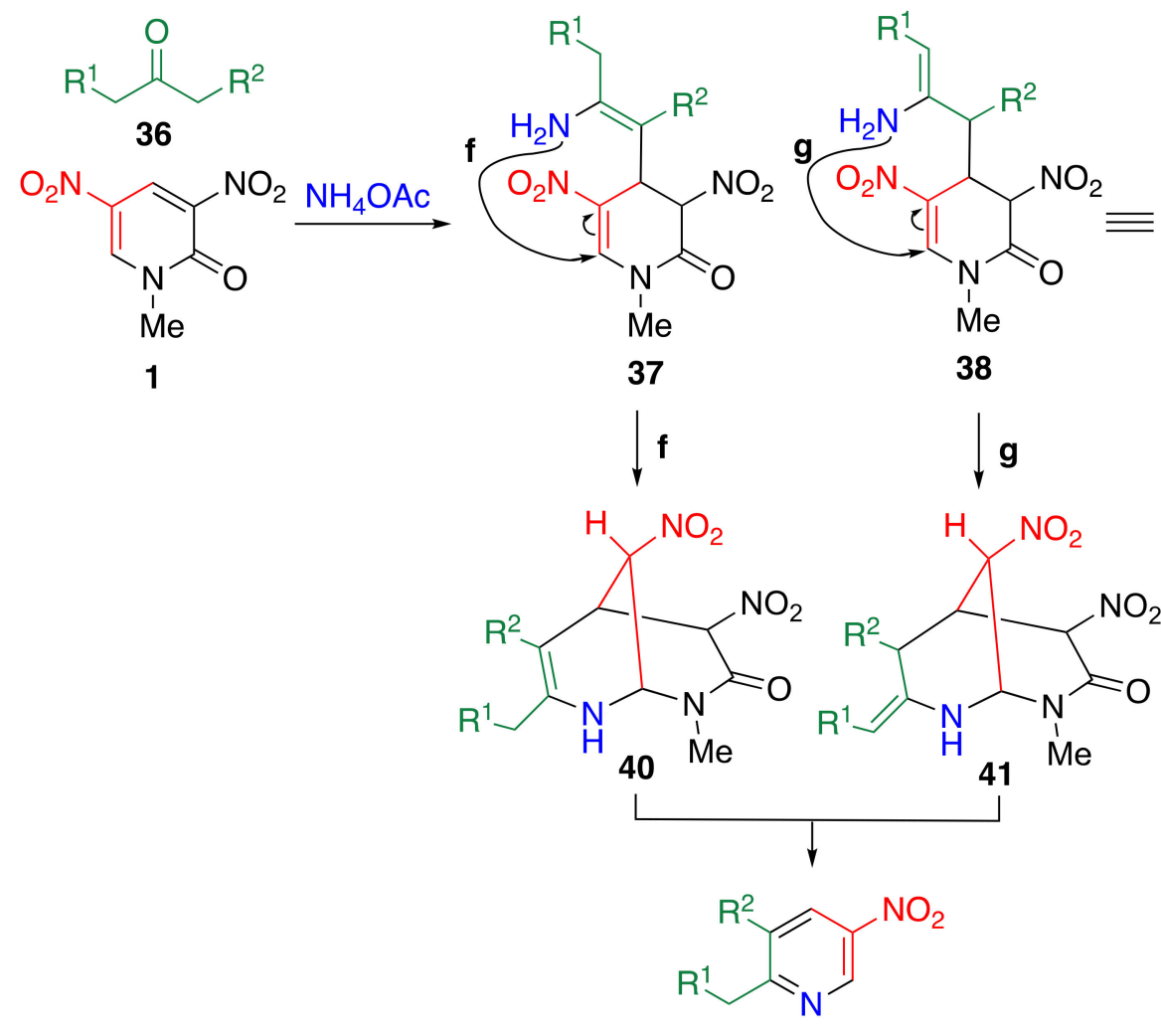

43

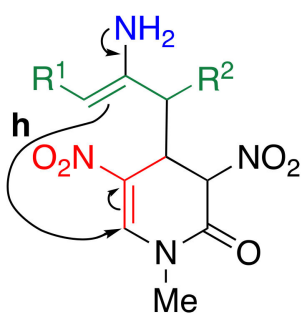

38

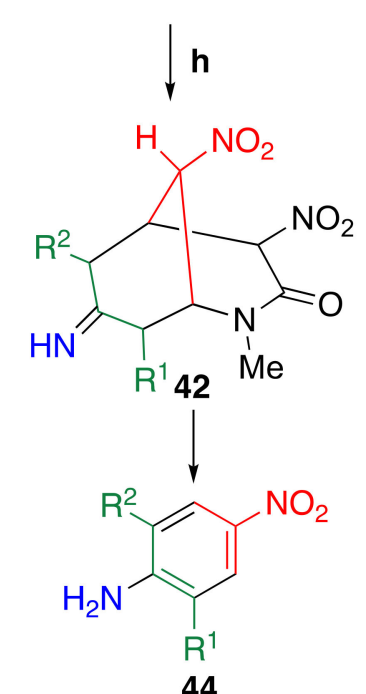

Scheme 13. Plausible mechanisms of TCRT when an aliphatic ketone 36 is employed as a reagent. 
In the reactions of pyridone 1 with cycloalkanone 13, only nitropyridine 14 is formed (Table 8). Although the adduct of 1 and cycloalkanone 13 can form two kinds of enamines, one enamine can form a six-membered ring as a result of $\mathrm{C}$-attack, and the formed intermediate 35 is too strained to be formed (Scheme 12).

\subsection{TCRT Using Aliphatic Ketones 36}

When dinitropyridone $\mathbf{1}$ is subjected to a reaction with aliphatic ketones 36 in the presence of ammonium acetate, two types of TCRT occur to afford nitropyridines 43 and nitroanilines 44 (Table 9) [56]. Generally, 2,6-disubstituted 4-nitroanilines 44 are prepared from the corresponding anilines by nitration under harsh reaction conditions, wherein protection and deprotection of the amino groups are necessary [57]. Furthermore, the preparation of this compound suffers from the limitation of Friedel-Crafts alkylation. There are several limitations for the Friedel-Crafts alkylation, such as the following: (1) The monoalkylated product undergoes further alkylation, (2) it is difficult to introduce two different alkyl groups, (3) primary alkyl groups longer than the ethyl group cannot be introduced, (4) a phenyl group cannot be introduced, and (5) nitrobenzene and aniline do not facilitate the alkylation. The TCRT overcomes these disadvantages.

Table 9. Two kinds of TCRT using aliphatic ketones 36.
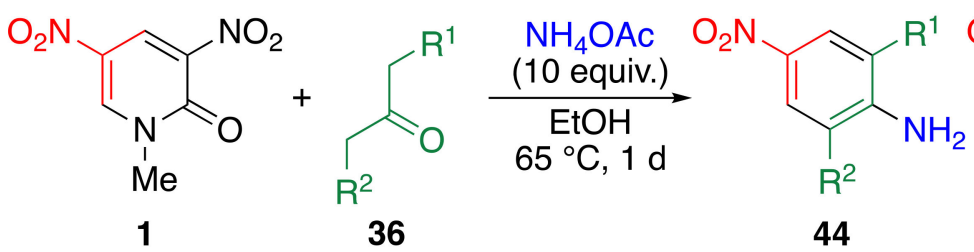<smiles>[R]Cc1ncc([N+](=O)[O-])cc1[R]</smiles><smiles>[R]Cc1ncc([N+](=O)[O-])cc1[R]</smiles>

36 44 43 43'

\begin{tabular}{|c|c|c|c|c|c|}
\hline \multicolumn{2}{|c|}{ Ketone } & & \multicolumn{3}{|c|}{ Yield $/ \%$} \\
\hline $\mathrm{R}^{1}$ & $\mathbf{R}^{2}$ & & 44 & 43 & $43^{\prime}$ \\
\hline $\mathrm{Me}$ & $\mathrm{Me}$ & $\mathbf{a}^{1}$ & 50 & 44 & - \\
\hline $\mathrm{Me}$ & $\mathrm{Me}$ & $\mathbf{a}$ & 83 & 13 & - \\
\hline $\mathrm{H}$ & $\mathrm{H}$ & $\mathbf{b}$ & 51 & 47 & - \\
\hline Et & $\mathrm{H}$ & c & 66 & 10 & 8 \\
\hline$i-\operatorname{Pr}$ & $\mathrm{H}$ & d & 58 & 0 & 31 \\
\hline $\operatorname{Pr}$ & $\mathrm{H}$ & e & 83 & 9 & 6 \\
\hline Et & Et & f & 67 & 24 & - \\
\hline $\operatorname{Pr}$ & $\operatorname{Pr}$ & g & 74 & 22 & - \\
\hline $\mathrm{C}_{6} \mathrm{H}_{5}$ & $\operatorname{Pr}$ & h & 62 & 24 & 13 \\
\hline $\mathrm{C}_{6} \mathrm{H}_{5}$ & $\mathrm{C}_{6} \mathrm{H}_{5}$ & $\mathbf{i}$ & 8 & 81 & - \\
\hline
\end{tabular}

${ }^{1}$ Five equivalents of ammonium acetate are used.

When dinitropyridone $\mathbf{1}$ is reacted with 3-pentanone in the presence of five equivalents of ammonium acetate, nitroaniline $44 \mathbf{a}$ and nitropyridine $43 \mathrm{a}$ are obtained at $50 \%$ and $44 \%$, respectively, resulting from two types of TCRT. In contrast, the ratio of $44 a$ to 43a increases significantly without a decrease in total yield, indicating the presence of an equilibrium between bicyclic intermediates 42 and 41 (Scheme 13). The substituents can be modified by altering only the ketones 36 (Table 9). Monoalkylated nitroanilines $44 \mathrm{c}-\mathbf{e}$ and unsymmetrical nitroanilines $44 \mathrm{~h}$ and $44 \mathrm{i}$ are available from the corresponding unsymmetrical ketones 36. Furthermore, it is easy to prepare nitroanilines $4 \mathbf{4} \mathbf{g}-\mathbf{i}$ possessing a propyl or phenyl group, which cannot be introduced by the Friedel-Crafts reaction. However, steric repulsion by the phenyl groups prevents the formation of bicyclic intermediate $42 \mathbf{i}$.

A combination of propylamine $45 \mathrm{~A}$ and acetic acid can be used as a reagent instead of ammonium acetate, which facilitates $N$-modification of the amino group as well as the benzene ring of nitroaniline $\mathbf{4 6}$ (Table 10). This method is applicable to secondary amines, pyrrolidine 45B and diethylamine 45C, to afford $N, N, 2,6$-tetrasubstituted 4-nitroanilines $46 \mathrm{~B}$ and $46 \mathrm{C}$, respectively. This reaction also enables the introduction of a propyl or phenyl 
group into the benzene framework, which cannot be introduced by the Friedel-Crafts reaction.

Table 10. Synthesis of N,N,2,6-tetrasubstituted 4-nitroanilines 46 by TCRT using aliphatic ketones 36 and dialkylammonium acetate 45 .

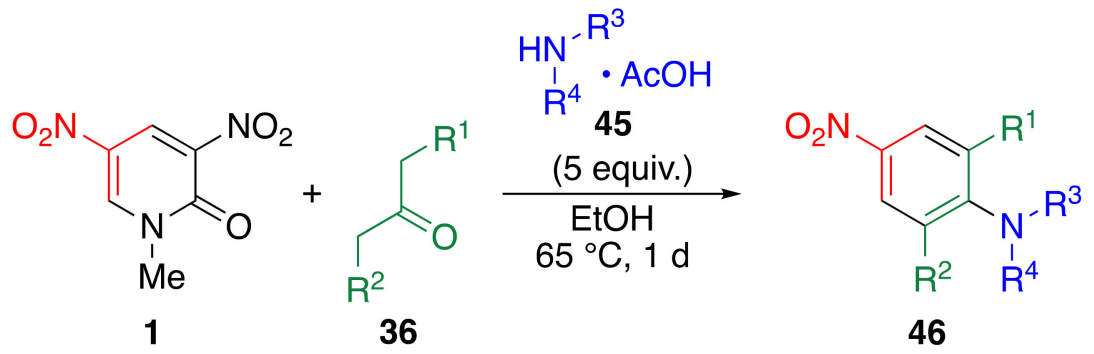

\begin{tabular}{|c|c|c|c|c|c|c|c|}
\hline \multicolumn{3}{|c|}{ Ketone } & \multicolumn{3}{|c|}{ Amine } & \multirow{2}{*}{ Product } & \multirow{2}{*}{ Yield/\% } \\
\hline $\mathbf{R}^{1}$ & $\mathbf{R}^{2}$ & & $\mathbf{R}^{3}$ & $\mathbf{R}^{4}$ & & & \\
\hline $\mathrm{Me}$ & $\mathrm{Me}$ & $36 a$ & $\operatorname{Pr}$ & $\mathrm{H}$ & $45 \mathrm{~A}$ & 46Aa & 99 \\
\hline $\mathrm{Me}$ & $\mathrm{Me}$ & $36 a$ & \multicolumn{2}{|c|}{$-\left(\mathrm{CH}_{2}\right)_{4}-$} & $45 B$ & $46 B a$ & 98 \\
\hline $\mathrm{Me}$ & $\mathrm{Me}$ & $36 a$ & Et & Et & $45 C$ & $46 \mathrm{Ca}$ & 98 \\
\hline Et & $\mathrm{H}$ & $36 c$ & $\operatorname{Pr}$ & $\mathrm{H}$ & $45 \mathrm{~A}$ & $46 \mathrm{Ac}$ & 83 \\
\hline Et & $\mathrm{H}$ & $36 c$ & \multicolumn{2}{|c|}{$-\left(\mathrm{CH}_{2}\right)_{4}^{-}$} & $45 B$ & $46 \mathrm{Bc}$ & 68 \\
\hline $\operatorname{Pr}$ & $\mathrm{H}$ & $36 \mathrm{e}$ & $\operatorname{Pr}$ & $\mathrm{H}$ & $45 \mathrm{~A}$ & 46Ae & 77 \\
\hline $\operatorname{Pr}$ & $\mathrm{H}$ & $36 \mathrm{e}$ & \multicolumn{2}{|c|}{$-\left(\mathrm{CH}_{2}\right)_{4}^{-}$} & 45B & 46Be & 87 \\
\hline $\operatorname{Pr}$ & $\mathrm{H}$ & $36 \mathrm{e}$ & Et & Et & $45 C$ & $46 \mathrm{Ce}$ & 51 \\
\hline$i-\operatorname{Pr}$ & $\mathrm{H}$ & $36 d$ & $\operatorname{Pr}$ & $\mathrm{H}$ & $45 \mathrm{~A}$ & 46Ad & 83 \\
\hline Et & Et & $36 f$ & $\operatorname{Pr}$ & $\mathrm{H}$ & $45 \mathrm{~A}$ & 46Af & 69 \\
\hline Et & Et & $36 f$ & \multicolumn{2}{|c|}{$-\left(\mathrm{CH}_{2}\right)_{4-}$} & 45B & $46 \mathrm{Bf}$ & 68 \\
\hline $\operatorname{Pr}$ & $\operatorname{Pr}$ & $36 \mathrm{~g}$ & $\operatorname{Pr}$ & $\mathrm{H}$ & $45 \mathrm{~A}$ & $46 \mathrm{Ag}$ & 81 \\
\hline $\operatorname{Pr}$ & $\operatorname{Pr}$ & $36 \mathrm{~g}$ & \multicolumn{2}{|c|}{$-\left(\mathrm{CH}_{2}\right)_{4-}$} & $45 B$ & $46 \mathrm{Bg}$ & 59 \\
\hline $\mathrm{C}_{6} \mathrm{H}_{5}$ & $\operatorname{Pr}$ & $36 \mathrm{~h}$ & $\operatorname{Pr}$ & $\mathrm{H}$ & $45 \mathrm{~A}$ & 46Ah & 80 \\
\hline $\mathrm{C}_{6} \mathrm{H}_{5}$ & $\mathrm{C}_{6} \mathrm{H}_{5}$ & $36 \mathbf{i}$ & $\operatorname{Pr}$ & $\mathrm{H}$ & $45 \mathrm{~A}$ & 46Ai & 32 \\
\hline
\end{tabular}

As shown in Scheme 13, the TCRT proceeds through the $C$-attack of the intermediately formed enamine 38. This means that functionalized nitoanilines 48 can be prepared if a similar structure is available via an alternative route. For this purpose, relatively stable enaminones $\mathbf{4 7}$ prepared from 1,3-dicarbonyl compounds $\mathbf{7}$ and amine $\mathbf{4 5}$ are considered suitable. When dinitropyridone 1 reacts with enaminone 47 , nucleophilic-type ring transformation proceeds to afford 2-functionalized 4-nitroaniline 48 (Table 11) [58]. This protocol facilitates the modification of the functional group and amino group of 48 by altering 1,3-dicarbonyl compounds 7 and amine 45 . Diketones $7 \mathbf{c}$ and $7 \mathbf{e}$ as well as keto easter $\mathbf{7 b}$ can be used as 1,3-dicarbonyl compounds. These reagents are not required to possess an acetyl group $\left(\mathrm{R}^{1}=\mathrm{H}\right)$, and $\mathbf{7 f}$ undergoes similar ring transformations. Bulky amines such as tert-butylamines 45D and 45E and less nucleophilic anilines 45F and 45G can be used as amines. Even though amines have a functional group, the corresponding nitroaniline $48 \mathrm{Hb}$ is obtained. Furthermore, cyclic and acyclic secondary amines $45 \mathrm{~B}$ and $45 \mathrm{C}$ can be used for this reaction, which results in 2-functionalized $N, N$-dialkyl-4-nitroanilines $48 \mathrm{Bc}$, $48 \mathrm{Ca}$, and $48 \mathrm{Ce}$. 
Table 11. Synthesis of 2-functionalized 4-nitroanilines 48.<smiles>[R]CC(=O)C([3H])CC([R7])=O</smiles>

1

47 48

\begin{tabular}{|c|c|c|c|c|c|c|c|c|}
\hline \multicolumn{3}{|c|}{ 1,3-Dicarbonyl Compound } & \multicolumn{3}{|c|}{ Amine } & \multirow{2}{*}{ Time/d } & \multirow{2}{*}{ Product } & \multirow{2}{*}{ Yield/\% } \\
\hline $\mathbf{R}^{1}$ & $\mathbf{R}^{2}$ & & $\mathbf{R}^{3}$ & $\mathbf{R}^{4}$ & & & & \\
\hline $\mathrm{H}$ & $\mathrm{Me}$ & $7 c$ & $\operatorname{Pr}$ & $\mathrm{H}$ & $45 \mathrm{~A}$ & 2 & $48 \mathrm{Ac}$ & 57 \\
\hline $\mathrm{H}$ & $\mathrm{Me}$ & $7 c$ & sec-Bu & $\mathrm{H}$ & 45D & 2 & $48 \mathrm{Ca}$ & 64 \\
\hline $\mathrm{H}$ & $\mathrm{Me}$ & $7 c$ & tert-Bu & $\mathrm{H}$ & $45 \mathrm{E}$ & 2 & $48 \mathrm{Ca}$ & 39 \\
\hline $\mathrm{H}$ & $\mathrm{Me}$ & $7 c$ & $\mathrm{C}_{6} \mathrm{H}_{5}$ & $\mathrm{H}$ & $45 \mathrm{~F}$ & 2 & 48Ac & 23 \\
\hline $\mathrm{H}$ & $\mathrm{Me}$ & $7 c$ & $4-\mathrm{MeC}_{6} \mathrm{H}_{4}$ & $\mathrm{H}$ & $45 G$ & 2 & $48 \mathrm{Gc}$ & 36 \\
\hline $\mathrm{H}$ & $\mathrm{Me}$ & $7 c$ & \multicolumn{2}{|c|}{$-\left(\mathrm{CH}_{2}\right)_{4}-$} & $45 B$ & 2 & 48BC & 87 \\
\hline $\mathrm{H}$ & $\mathrm{C}_{6} \mathrm{H}_{5}$ & $7 e$ & $\operatorname{Pr}$ & $\mathrm{H}$ & $45 \mathrm{~A}$ & 4 & 48Ae & 33 \\
\hline $\mathrm{H}$ & $\mathrm{C}_{6} \mathrm{H}_{5}$ & $7 e$ & Et & Et & $45 \mathrm{C}$ & 2 & $48 \mathrm{Ce}$ & 45 \\
\hline $\mathrm{H}$ & OEt & $7 \mathrm{~b}$ & $\operatorname{Pr}$ & $\mathrm{H}$ & $45 \mathrm{~A}$ & 1 & $48 \mathrm{Ab}$ & 61 \\
\hline $\mathrm{H}$ & $\mathrm{OEt}$ & $7 \mathbf{b}$ & $\mathrm{HOCH}_{2} \mathrm{CH}_{2}$ & $\mathrm{H}$ & $45 \mathrm{H}$ & 1 & $48 \mathrm{Hb}$ & 45 \\
\hline $\mathrm{H}$ & $\mathrm{OEt}$ & $7 \mathbf{b}$ & Et & Et & $45 C$ & 1 & $48 \mathrm{Cb}$ & 57 \\
\hline Et & $\mathrm{OEt}$ & $7 f$ & $\operatorname{Pr}$ & $\mathrm{H}$ & $45 \mathrm{~A}$ & 2 & 48Af & 24 \\
\hline
\end{tabular}

\section{Conclusions}

When dinitropyridone $\mathbf{1}$ is subjected to a reaction with cycloalkanones $\mathbf{1 3}$ in the presence of ammonia, nucleophilic-type TCRT efficiently proceeds to afford nitrated cycloalka[b]pyridines 14. In this reaction, pyridone 1 serves as a synthetic equivalent of unstable NMA-H. However, this method is applicable only to cycloalkanones $\mathbf{1 3}$, as the competitive ammonolysis of $\mathbf{1}$ cannot be ignored in cases of other types of ketones.

This disadvantage is overcome by using the less nucleophilic ammonium acetate as a nitrogen source instead of ammonia. Aromatic ketones 15, alkenyl ketones 26, alkynyl ketones 28, and aldehyde 30 undergo TCRT to furnish the corresponding pyridines that are not easily available by alternative methods, including transition-metal-catalyzed coupling reactions. When acyclic aliphatic ketones $\mathbf{3 6}$ are used as the reagent, the TCRT proceeds in different modes to give 4-nitroaniline derivatives 44 . In this reaction, a combination of amine and acetic acid is usable, leading to the synthesis of $N, N, 2,6$-tetrasubstituted 4-nitroanilines 46. Furthermore, functionalized nitroanilines 48 are available using enaminones 47 as a reagent.

In addition to the easy modification of the product framework, the reaction is conducted under mild conditions with simple experimental manipulations, which are more practical. These features facilitate the construction of a library of compounds that are not easily available by other methods. In particular, compounds possessing both electrondonating and electron-withdrawing groups (push-pull systems) are necessary for developing novel functional materials such as medicines, agrochemicals, and non-linear optical materials. Therefore, the TCRT will provide a new synthetic tool for researchers studying in this field.

Author Contributions: Original draft preparation, S.T.L. and N.N.; total discussion, H.A. All authors have read and agreed to the published version of the manuscript. 
Funding: This research received no external funding.

Conflicts of Interest: The authors declare no conflict of interest.

\section{References}

1. Xue, J.; Gao, E.; Wang, X.-N.; Chang, J. Metal-Free Formal Inverse-Electron-Demand Diels-Alder Reaction of 1,2-Diazines with Ynamides. Org. Lett. 2018, 20, 6055-6058. [CrossRef] [PubMed]

2. Rastogi, S.K.; Medellin, D.C.; Kornienko, A. C-H Functionalization Directed by Transformable Nitrogen Heterocycles: Synthesis of ortho-Oxygenated Arylnaphthalenes from Arylphthalazines. Org. Biomol. Chem. 2014, 12, 410-413. [CrossRef] [PubMed]

3. Huntley, R.J.; Gurram, M.; Walker, J.R.; Jenkins, D.M.; Robe, E.J.; Ahmed, F. Synthesis of Isoindolinones via Inverse-Electron Demand Diels-Alder Cycloadditions. Tetrahedron Lett. 2014, 55, 2286-2289. [CrossRef]

4. Firsov, A.; Bakulina, O.; Dar'in, D.; Guranova, N.; Krasavin, M. Further Insight into the Castagnoli-Cushman-type Synthesis of 1,4,6-Trisubstituted 1,6-Dihydropyridin-2-(3H)-ones from 3-Arylglutaconic Acid Anhydrides. J. Org. Chem. 2020, 85, 6822-6829. [CrossRef]

5. Khalifa, M.M.; Philkhana, S.C.; Golden, J.E. Synthesis of Ring-Fused, N-Substituted 4-Quinolinones Using pK $K_{a}$-Guided, BasePromoted Annulations with Isatoic Anhydrides: Total Synthesis of Penicinotam. J. Org. Chem. 2020, 85, 464-481. [CrossRef]

6. Laws, S.W.; Moore, L.C.; Di Maso, M.J.; Nguyen, Q.N.N.; Tantillo, D.J.; Shaw, J.T. Diastereoselective Base-Catalyzed Formal [4 + 2] Cycloadditions of N-Sulfonyl Imines and Cyclic Anhydrides. Org. Lett. 2017, 19, 2466-2469. [CrossRef]

7. Van der Plas, H.C. Degenerate Ring Transformations in Heterocyclic Systems. J. Heterocycl. Chem. 2000, 37, 427-438. [CrossRef]

8. Glinkerman, C.M.; Boger, D.L. Synthesis, Characterization, and Rapid Cycloadditions of 5-Nitro-1,2,3-triazine. Org. Lett. 2018, 18, 2628-2631. [CrossRef] [PubMed]

9. Nishiwaki, N.; Sugimoto, R.; Saigo, K.; Kobiro, K. Mechanistic Aspect of Ring Transformations in the Reaction of 5-Nitro-4pyrimidinone with Acetophenone Derivatives and Cycloalkanones Depending on the Electron Density/Ring Size of the Ketone. Tetrahedron Lett. 2013, 54, 956-959. [CrossRef]

10. Nishiwaki, N.; Yamashita, K.; Azuma, M.; Adachi, T.; Tamura, M.; Ariga, M. Novel Synthesis of Bihetaryl Compounds. Synthesis 2004, 1996-2000. [CrossRef]

11. Nishiwaki, N.; Azuma, M.; Tamura, M.; Hori, K.; Tohda, Y.; Ariga, M. Facile Synthesis of Functionalized 4-Aminopyridines. Chem. Commun. 2002, 2170-2171. [CrossRef] [PubMed]

12. Gromov, S.P. Ring Transformation of Pyridines and Benzo Derivatives under the Action of C-Nucleophiles. Heterocycles 1995, 40, 441-475. [CrossRef]

13. Rusinov, V.L.; Chupakhin, O.N. Transformations of Nitropyrimidines by Action of C-Nucleophiles. Heterocycles 2000, 53, 1607-1630.

14. Fanta, P.E.; Stein, R.A. The Chemistry of Sodium Nitromalonaldehyde. Chem. Rev. 1960, 60, 261-266. [CrossRef]

15. Nishiwaki, N.; Hirao, S.; Sawayama, J.; Saigo, K. Practically Usable C3 Building Blocks for the Syntheses of Nitro Heterocycles. Heterocycles 2012, 84, 115-134. [CrossRef]

16. Tohda, Y.; Ariga, M.; Kawashima, T.; Matsumura, E. The Nucleophilic Reaction upon Electron-Deficient Pyridone Derivatives. VIII. Novel Fragmentation of 3,5-Dinitro-2-pyridone by Primary Amine. Bull. Chem. Soc. Jpn. 1987, 60, 201-204. [CrossRef]

17. Takaichi, J.; Ohkubo, K.; Sugimoto, H.; Nakano, M.; Usa, D.; Maekawa, H.; Fujieda, N.; Nishiwaki, N.; Seki, S.; Fukuzumi, S.; et al. Copper Complexes of the Non-Innocent $\beta$-Diketiminate Ligand Containing Phenol Groups. Dalton Trans. 2013, 42, 2438-2444. [CrossRef]

18. Shimokawa, C.; Tachi, Y.; Nishiwaki, N.; Ariga, M.; Itoh, S. Structural Characterization of Copper(I) Complexes Supported by $\beta$-Diketiminate Ligands with Different Substitution Pattern. Bull. Chem. Soc. Jpn. 2006, 79, 118-125. [CrossRef]

19. Shimokawa, C.; Yokota, S.; Tachi, Y.; Nishiwaki, N.; Ariga, M.; Itoh, S. Substituent Effects of $\beta$-Diketiminate Ligands on the Structure and Physicochemical Properties of Copper(II) Complexes. Inorg. Chem. 2003, 42, 8395-8405. [CrossRef]

20. Nishiwaki, N.; Tohda, Y.; Ariga, M. Facile Synthesis of Functionalized Nitroenamines. III. Aminolysis of 1-Methyl-5nitropyrimidin-2(1H)-one. Bull. Chem. Soc. Jpn. 1996, 69, 1997-2002. [CrossRef]

21. Matsumura, E.; Ariga, M.; Tohda, Y. The Nucleophilic Reaction of Electron-Deficient Pyridone Derivatives. I. The Ring Transformation of 1-Substituted 3,5-Dinitro-2-pyridones with Sodio $\beta$-Keto Esters. Bull. Chem. Soc. Jpn. 1979, 52, 2413-2419. [CrossRef]

22. Ariga, M.; Tohda, Y.; Matsumura, E. Ring Transformation of 1,4 (or 1,6)-Disubstituted 3,5-Dinitro-2-pyridones with Sodio $\beta$-Keto Esters. Bull. Chem. Soc. Jpn. 1985, 58, 393-394. [CrossRef]

23. Nishiwaki, N.; Tohda, Y.; Ariga, M. Nitropyrimidinones; Synthetic Equivalents of Diformylamine and Nitromalonaldehyde. Synthesis 1997, 1277-1280. [CrossRef]

24. Tohda, Y.; Eiraku, M.; Nakagawa, T.; Usami, Y.; Ariga, M.; Kawashima, T.; Tani, K.; Watanabe, H.; Mori, Y. The Nucleophilic Reaction upon Electron-Deficient Pyridone Derivatives. X. One-Pot Synthesis of 3-Nitropyridines by Ring Transformation of 1-Methyl-3,5-dinitro-2-pyridone with Ketones or Aldehydes in the Presence of Ammonia. Bull. Chem. Soc. Jpn. 1990, 63, $2820-2827$. [CrossRef]

25. Drescher, K.; Haupt, A.; Unger, L.; Turner, S.C.; Braje, W.; Grandel, R.; Henry, C. Preparation of Aminotetrahydronaphtalenylbenzenesulfonamides and Related Compounds as Modulators of the Dopamine D3 Receptor. WO 2006040178, 20 April 2006. 
26. Yuan, J.; Han, N.; Yi, H.; Wang, Y.; Yang, S.; Wong, J.C. Preparation of Potent Small molecule inhibitors of Autophagy Useful in Treatment of Cancers and Acute Pancreatitis. WO 2014145512, 18 September 2014.

27. Ge, M.; Yang, L.; Zhou, C.; Lin, S.; Cline, E. Preparation of Fused Pyridines as Antidiabetics. WO 2006083612,10 August 2006.

28. Bauta, W.E.; Cantrell, W.R.; Tidwell, M.W. Preparation of Hydroxyimino Tetrahydroquinoline Compounds as Reactivators of Organophosphorous-Inhibited Acetylcholinesterase. US 20140350262, 27 November 2014.

29. Kelly, M.G.; Kaub, C.J.; Kincaid, J.; Janagani, S.; Wu, G.; Wei, Z.-L.; Sahasrabudhe, K.; Duncton, M.; Upasani, R.B.; Fang, Y.; et al. Preparation of Amide Derivatives as Ion-Channel Ligands. WO 2007100758, 7 September 2007.

30. Ananthan, S.; Kezar, H.S., III; Saini, S.K.; Khare, N.K.; Davis, P.; Dersch, C.M.; Porreca, F.; Rothman, R.B. Synthesis, Opioid Receptor Binding, and Functional Activity of 5'-Substituted 17-Cyclopropylmethylpyrido[2',3':6,7]morphinas. Bioorg. Med. Chem. Lett. 2003, 13, 529-532. [CrossRef]

31. Coulton, S.; Harling, J.D.; Porter, R.A.; Thompson, M. Preparation of Substituted Isoquinolines as Anticonvulsants. WO 200008020, 17 February 2020.

32. Aicher, T.D.; Skalitzky, D.J.; Toogood, P.L.; Vanhuis, C.A. Preparation of Dihydroisoquinoline-2(1H)-carboxamides and Related Compounds and Their Use in Treating Medical Conditions. WO 2019200120, 17 October 2019.

33. Coulton, S.; Novelli, R.; Porter, R.; Thompson, M.; Ward, R.W. Preparation of Pyrido[2,1-a]isoquinolines and Pyrrolo[2,1a]isoquinolines as Anticonsuvulsants. WO 200008020, 17 February 2020.

34. Guiadeen, D.; Kothandaraman, S.; Yang, L.; Mills, S.G.; MacCoss, M. An Expeditious Synthesis of 3-(Difluoromethoxy)- and 3-(Trifluoromethoxy)-5,6,7,8-tetrahydro-1,6-naphthyridines. Tetrahedron Lett. 2008, 49, 6368-6370. [CrossRef]

35. DeMartino, J.; Akiyama, T.; Struthers, M.; Yang, L.; Berger, J.P.; Morriello, G.; Pastemak, A.; Zhou, C.; Mills, S.G.; Kothandaraman, S.; et al. Preparation of Tetrahydropyranylaminocyclopentylcarbonyltetrahydropyridopyridines as Modulators of CCR2 Chemokine Receptor Activity. WO 20060030582, 9 February 2006.

36. Harling, J.D.; Harrington, F.P.; Thompson, M. A Facile Synthesis of the 3-Amino-5,6,7,8-tetrahydro[1,6]naphthyridine System and Some Alkylated and Polycyclic Homologues. Synth. Commun. 2001, 31, 787-797. [CrossRef]

37. Berger, R.; Blizzard, T.A.; Campbell, B.T.; Chen, H.Y.; Debenham, J.S.; Dewnani, S.V.; Dubois, B.; Guo, Z.; Harper, B. Preparation of Isoquinoline Derivatives as MGAT2 Inhibitors. WO 2015112465, 30 July 2015.

38. Aicher, T.D.; van Huis, C.A.; Thomas, W.D.; Maclean, J.K.; Andersen, B.M.; Barr, K.J.; Bienstock, C.E.; Anthony, N.J.; Daniels, M.; Liu, K.; et al. Preparation of Tetrahydronaphthyridines, Benzoxazines, Azabenzoxazines, and Related Bicyclic Compounds for Inhibition of RORgamma Activity and the Treatment of Disease. WO 2015095795, 25 June 2015.

39. Stansfield, I.; Querolle, O.A.G.; Ligny, Y.A.E.; Gross, G.M.; Jacoby, E.; Meerpoel, L.; Green, S.R.; Hynd, G.; Kulagowski, J.J.; Macleod, C.; et al. Cyanoindoline Derivatives as NIK Inhibitors and Their Preparation. WO 2018002219, 4 January 2018.

40. Takada, S.; Sasatani, T.; Chomei, N.; Adachi, M.; Fujishita, T.; Eigyo, M.; Murata, S.; Kawasaki, K.; Matsushita, A. Synthesis and Structure-Activity Relationship of Fused Imidazopyridines: A New Series of Benzodiazepine Receptor Ligands. J. Med. Chem. 1996, 39, 2844-2851. [CrossRef]

41. Barfoot, C.; Davies, D.T.; Miles, T.; Pearson, N.D. Bicyclic Nitrogen-Containing Compounds as Mycobacterium Tuberculosis H37Rv Inhibitors and Their Preparation, Pharmaceutical Compositions and Use in the Treatment of Bacterial Infections. WO 2008128961, 30 October 2008.

42. Frank, R.; Christoph, T.; Lesch, B.; Lee, J. Preparation of Substituted Bicyclic Aromatic Carboxamide and Urea Derivatives as Vanilloid Receptor Ligands. WO 2013013816, 31 January 2013.

43. Bell, I.M.; Fraley, M.; Biftu, T.; Zhu, C.; Nair, A. Heterocyclic CGRP Receptor Antagonists for Migraine Therapy. WO 2013169565, 14 November 2013.

44. Henry, C.; Haupt, A.; Turner, S.C. Microwave-Assisted Synthesis of Novel (5-Nitropyridin-2-yl)alkyl and (5-Nitropyridin-3yl)alkyl Carbamates. J. Org. Chem. 2009, 74, 1932-1938. [CrossRef]

45. Vara Prasad, J.V.N.; Boyer, F.E.; Chupak, L.; Dermyer, M.; Ding, Q.; Gavardinas, K.; Hagen, S.E.; Huband, M.D.; Jiao, W.; Kaneko, T.; et al. Synthesis and Structure-Acitivity Studies of Novel Benzocycloheptanone Oxazolidinone Antibacterial Agents. Bioorg. Med. Chem. Lett. 2006, 16, 5392-5397. [CrossRef] [PubMed]

46. Chupak, L.S.; Kaneko, T.; Josyula, V.P.V.N.; Kim, J.-Y.; Choy, A.L.; Hagen, S.E.; Boyer, F.E., Jr. Preparation of Tricyclyl-Substituted Oxazolidinones and Related Compounds as Antibacterial Agents. WO 2004069832, 19 August 2004.

47. Schultz, T.; Turner, S.C.; Braje, W.M. Microwave-Assisted Synthesis of Nitro-Substituted Tetrahydropyridoazepines. Synthesis 2010, 1339-1343.

48. Goff, D.; Zhang, J.; Singh, R.; Holland, S.; Yu, J.; Heckrodt, T.; Ding, P.; Litvak, J. Preparation of Polycyclic Aryl and Heteroaryl Substituted Triazoles as AXL Receptor Tyrosine Kinase Inhibitors. WO 2009054864, 30 April 2009.

49. Sagitullina, G.P.; Garkushenko, A.K.; Vinokurova, Y.O.; Nyrkova, V.A.; Atavin, E.G.; Sagitullin, R.S. Nitropyridines: VI. Synthesis of 2-aryl(hetaryl)- and 2,3-polymethylene-5-nitropyridines. Russ. J. Org. Chem. 2009, 45, 1045-1049.

50. Kato, K.; Terauchi, J.; Mori, M.; Suzuki, N.; Shimomura, Y.; Takekawa, S.; Ishihara, Y. Preparation of N-Tetrahydronaphthalenyl Carboxamides as Melamin Concentrating Hormone Antagonists. WO 0121577, 29 March 2001.

51. Le, T.S.; Asahara, H.; Kobiro, K.; Sugimoto, R.; Saigo, K.; Nishiwaki, N. Synthesis of 2-Aryl-5-nitropyridines by Three-Component Ring Transformation of 3,5-Dinitro-2-pyridone. Asian J. Org. Chem. 2014, 3, 297-302. [CrossRef]

52. Le, T.S.; Asahara, H.; Nishiwaki, N. Metal-Free Synthesis of 2-Alkenyl/Alkynyl-5-nitropyridines Using Three-Component Ring Transformation. Chem. Lett. 2015, 44, 776-778. [CrossRef] 
53. Furuyama, H.; Kurihara, H.; Terao, T.; Nakagawa, D.; Tanabe, S.; Kato, T.; Yamamoto, M.; Sekine, S.; Mashiko, T.; Inuki, S.; et al. Preparation of Nitrogen-Containing Heterocyclic Compounds as PI3K and ERK Inhibitors. WO 2014109414, 17 July 2014.

54. Le, T.S.; Asahara, H.; Nishiwaki, N. An Alternative Synthetic Approach to 3-Alkylated/Arylated 5-Nitropyridines. J. Org. Chem. 2015, 80, 8856-8858. [CrossRef]

55. Le, T.S.; Asahara, H.; Nishiwaki, N. An Efficient Synthesis of Nitrated Cycloalka[b]pyridines. Synthesis. 2014, 46, 2175-2178.

56. Le, T.S.; Asahara, H.; Nishiwaki, N. Tailor-Made Synthesis of N,N,2,6-Tetrasubstituted 4-Nitroanilines by Three-Component Ring Transformation of Dinitropyridone. Eur. J. Org. Chem. 2015, 2015, 1203-1206. [CrossRef]

57. Carver, F.J.; Hunter, C.A.; Livingstone, D.J.; McCabe, J.F.; Seward, E.M. Substituent Effects on Edge-to-Face Aromatic Interactions. Chem. Eur. J. 2002, 8, 2847-2859. [CrossRef]

58. Naito, S.; Yokoyama, S.; Asahara, H.; Nishiwaki, N. Synthesis of Functionalized 4-Nitroanilines by Ring Transformation of Dinitropyridone with Enaminones. Tetrahedron Lett. 2017, 58, 4699-4702. [CrossRef] 